ENDING SLAVERY 



\section{Ending Slavery}

\section{How We Free Today's Slaves}

KEVIN BALES

甲

UNIVERSITY OF CALIFORNIA PRESS BERKELEY LOS ANGELES LONDON 
University of California Press, one of the most distinguished university presses in the United States, enriches lives around the world by advancing scholarship in the humanities, social sciences, and natural sciences. Its activities are supported by the UC Press Foundation and by philanthropic contributions from individuals and institutions. For more information, visit www.ucpress.edu.

University of California Press

Berkeley and Los Angeles, California

University of California Press, Ltd.

London, England

(C) 2007 by The Regents of the University of California

Library of Congress Cataloging-in-Publication Data Bales, Kevin.

Ending slavery : how we free today's slaves / Kevin Bales.

p. $\mathrm{cm}$.

Includes bibliographical references and index. ISBN 978-0-520-25470-I (cloth : alk. paper)

I. Slavery-History-2 Ist century. 2. Antislavery movements. 3. Poor-Employment.

I. Title.

HT867.B356 2007

306.3 '620905-dc22

2007008235

Manufactured in the United States of America

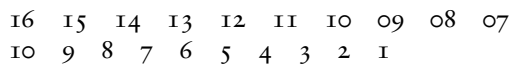

This book is printed on New Leaf EcoBook 50, a I00\% recycled fiber of which $50 \%$ is de-inked post-consumer waste, processed chlorine-free. EcoBook 50 is acid-free and meets the minimum requirements of ANSI/ASTM D5634-OI (Permanence of Paper). 